Check for updates

Cite this: RSC Adv., 2017, 7, 42000

\section{A green approach to the synthesis of a nano catalyst and the role of basicity, calcination, catalytic activity and aging in the green synthesis of 2-aryl bezimidazoles, benzothiazoles and benzoxazoles}

\begin{abstract}
Pramod K. Sahu*
A green synthesis of hydrotalcite (a double layered catalyst) by a grinding method using Al/Mg molar ratios of 1.0-3.0 at room temperature is described. The prepared double layered catalyst (hydrotalcite) has been characterized by TG, FT-IR, SEM, XRD and Hammett titration methods. Different factors such as the effect of molar ratios, catalyst loading, reaction time, aging time, and basicity have been investigated for the facile, efficient and green synthesis of 2-arylbenzimidazoles, benzothiazoles and benzoxazoles under solvent free conditions. The influence of catalyst loading on reactivity was studied and a catalyst loading of $20 \mathrm{mg}$ was found to be optimal, giving the best yield with minimum time as compared to other catalysts. The present methodology reports, herein, a rapid and cost effective synthesis of hydrotalcite and its versatile applications in the synthesis of 2 -arylbenzimidazoles, benzothiazoles and benzoxazoles.
\end{abstract}

Received 15th October 2016 Accepted 25th November 2016

DOI: 10.1039/c6ra25293a

rsc.li/rsc-advances lamellar solids. The main property of hydrotalcites is their anion exchange capacity, which makes them unique inorganic materials to intercalate organic or inorganic anion. ${ }^{8}$ Hydrotalcites are increasingly regarded as a good alternative to the traditional homogenous base catalysts such as $\mathrm{NaOH}$ and $\mathrm{KOH}$ for several base-catalyzed reactions that are important for the pharmaceutical and fragrance industries, ${ }^{9}$ electrode modifiers and catalyst supports. ${ }^{10}$ A well-documented example is the isomerization of eugenol and safrole. ${ }^{11}$ The structure consists of positively charged brucite (magnesium hydroxide)-like layers with interlayer space containing charge compensating anions and water molecules. ${ }^{\mathbf{1 2}}$ As far as green chemistry is concerned, hydrotalcites offer several advantages over corrosive and dissolved catalysts; easy separation from the reaction mixture, recycling possibilities, decreased corrosion of the reactor. ${ }^{\mathbf{1 3}}$ Hydrotalcites can be implicated in the preparation of catalysts dedicated to the production of $\mathrm{H}_{2},{ }^{14}$ wide range of organic compounds, ${ }^{\mathbf{1 5}}$ and production of biodiesel by trans-esterification of triglycerides with methanol. ${ }^{16}$ In addition to the above numerous experimental investigations have been published on the use of hydrotalcites for catalytic applications. ${ }^{17}$

Considering all above issues, there is a need to develop environmental benign green route and search new catalyst for the synthesis of benzimidazoles, benzothiazoles, and benzoxazoles. Hydrotalcite have higher catalytic activity due to high surface area than their bulk counterparts and due to this they have attracted considerable attention in organic synthesis. Therefore, as a part of our ongoing research aimed at the development of new catalysts and their application in synthesis of hetrocycles, ${ }^{18}$ we report herein, a rapid and cost effective 


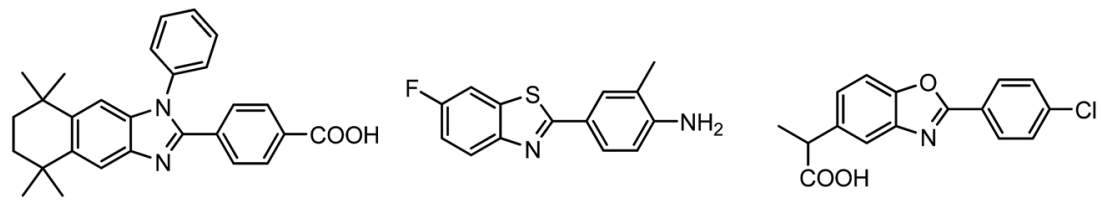

Fig. 1 Some benzimidazoles, benzothiazoles, and benzoxazoles.

Scheme 1

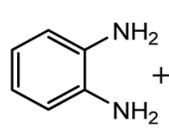

1

Scheme 2<smiles>[NH3+]c1ccccc1S</smiles>

4<smiles>Nc1ccccc1O</smiles>

6<smiles>[R]c1cccc(C=O)c1</smiles><smiles>[R]c1cccc(C=O)c1</smiles><smiles>[R]c1cccc(C=O)c1</smiles>

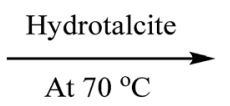<smiles>[R]c1ccc(-c2nc3ccccc3[nH]2)cc1</smiles>

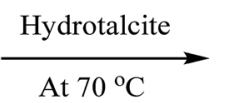<smiles>[R]c1ccc(-c2nc3ccccc3s2)cc1</smiles>

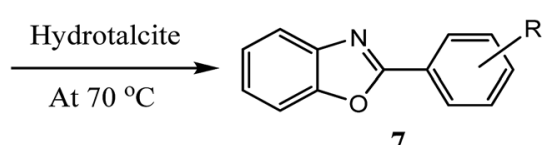

Fig. 2 Reaction of 1,2-phenylenediamine, 2-aminothiophenol, and 2-aminophenol with aldehyde respectively using hydrotalcite.

method (grinding method) for synthesis of hydrotalcite and used in synthesis of benzimidazoles, benzothiazoles, and benzoxazoles under solvent free conditions (Fig. 2).

\section{Results and discussion}

\section{Characterization of hydrotalcite}

Absorption band at higher wave numbers 3695 and $3471 \mathrm{~cm}^{-1}$ in IR spectra (Fig. 3) assigned to the $\mathrm{O}-\mathrm{H}$ stretching vibrations of water bonded to $\mathrm{M}^{3} \mathrm{OH}$ units. The shorter $\mathrm{O}-\mathrm{H}$ bonds existing in hydrotalcite causes an increase in electrostatic attraction

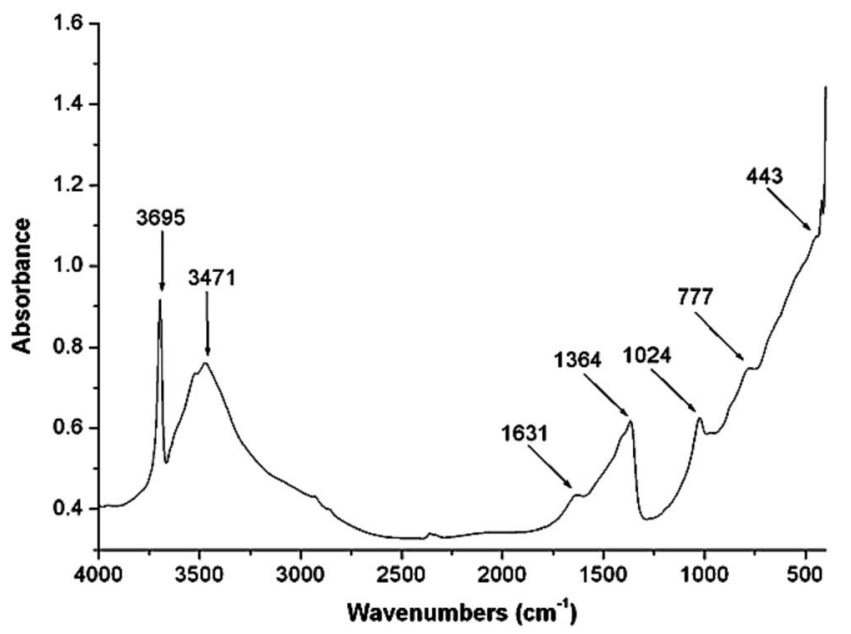

within the hydrotalcite layers. ${ }^{19}$ The weak bands at $2930 \mathrm{~cm}^{-1}$ and $2880 \mathrm{~cm}^{-1}$ are suggested to the strongly hydrogen bonded water molecules to interlayer anions such as carbonate. ${ }^{20}$ Strong water deformation modes at $1631 \mathrm{~cm}^{-1}$ found due to hydrotalcites containing physically adsorbed water. ${ }^{19}$ Carbonate which is bonded to hydroxyl surface of hydrotalcite shown a band at $1364 \mathrm{~cm}^{-1} .^{20}$ The IR absorption band at $1024 \mathrm{~cm}^{-1}$ has been assigned to symmetric stretch of free carbonate canions. ${ }^{19}$ Bending vibration of free carbonate anions give a band at $777 \mathrm{~cm}^{-1}$. The IR absorption band at $443 \mathrm{~cm}^{-1}$ has been assigned to Al-O bonds. ${ }^{21}$

$\mathrm{Mg}$ : Al atomic ratio was measured using X-ray microanalysis and found 3.16, which is in good agreement with the metallic ratio (3.0) taken in solution. The value of $x\left[x=\mathrm{M}^{\mathrm{III}} / \mathrm{M}^{\mathrm{II}}+\mathrm{M}^{\mathrm{III}}\right]$ was found to 0.24 , which suggest the purity of hydrotalcite. ${ }^{22}$ Powder X-ray diffraction (P-XRD) pattern for sample $\mathrm{Mg}-\mathrm{Al}-\mathrm{CO}_{3}$ is shown in Fig. 4. The presence of $\mathrm{CO}_{3}{ }^{2-}$ anion in the interlayer gallery of the hydrotalcite is confirmed by the characteristic basal spacing $d_{003}=7.76 \AA$. This indicates a gallery height of $2.96 \AA$ (assuming a thickness of $4.8 \AA$ for the cationic sheets). The material is reasonably crystalline and suggests a relatively well-ordered sheet arrangement. ${ }^{23}$ The crystallite size of this sample was found $24.87 \mathrm{~nm}$ as calculated using Scherrer formula. ${ }^{24}$ More intensive and sharper reflections of the (003) and (006) planes has found at low $2 \theta$ values $\left(11-23^{\circ}\right)$. A typical SEM image of $\mathrm{Mg}-\mathrm{Al}-\mathrm{CO}_{3}$ hydrotalcite is shown in Fig. 4 . This figure indicates the existence of lamellar particles looks like rounded hexagonal shape and typical of hydrotalcite like

Fig. 3 FT-IR spectra of the hydrotalcite $\left(\mathrm{Mg}-\mathrm{Al}-\mathrm{CO}_{3}\right)$. 


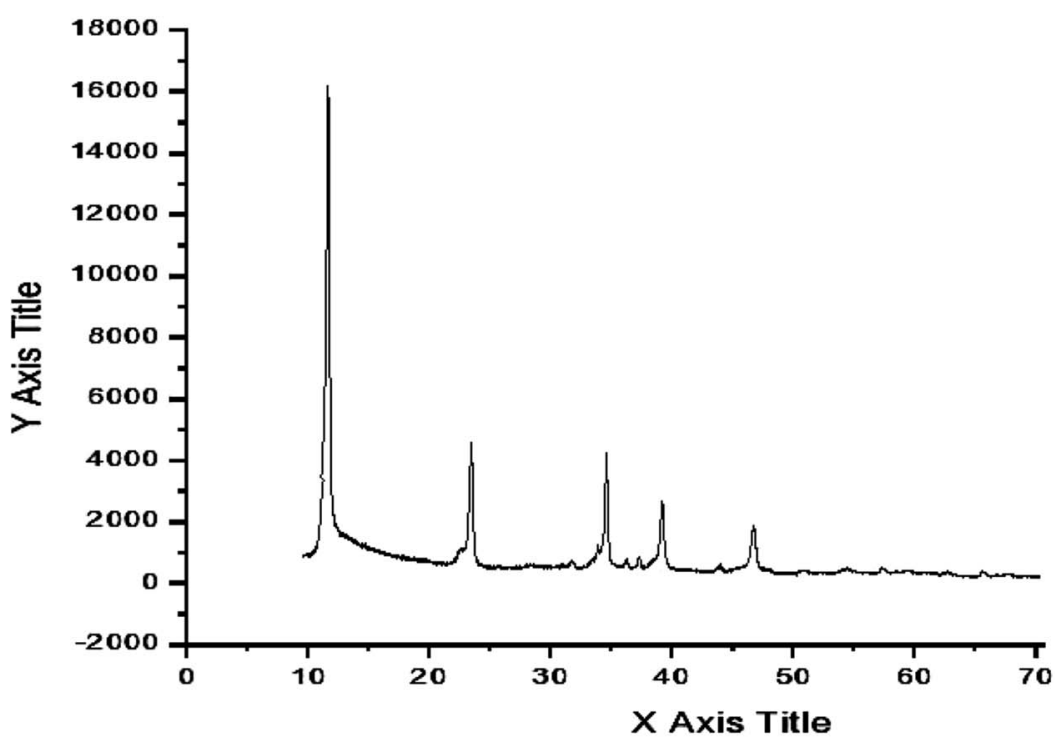

\section{XRD Pattern Mg-Al- 3:1}

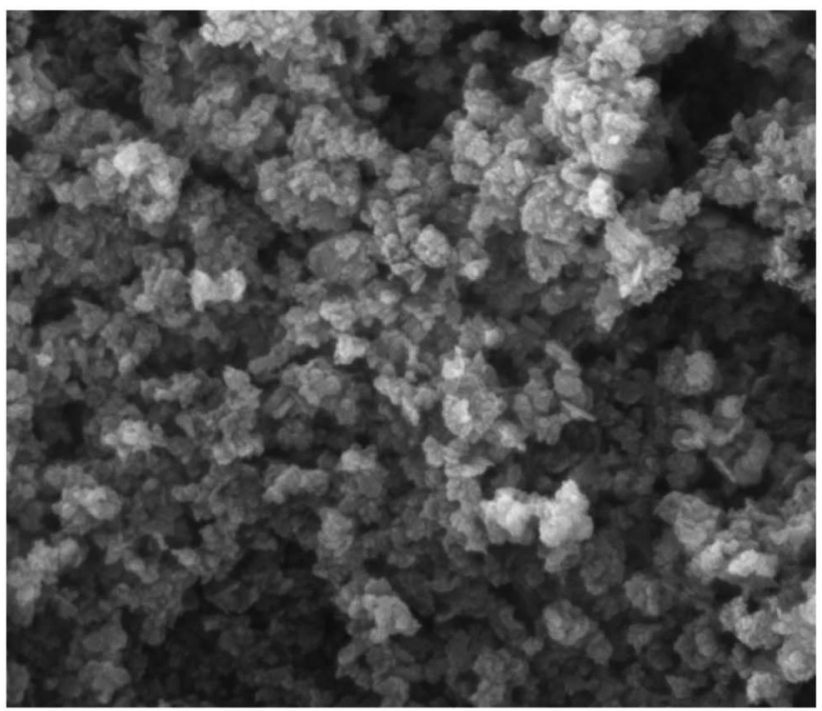

SEM Image Mg-Al- 3:1

Fig. 4 XRD pattern and SEM image of hydrotalcite $(\mathrm{Mg}-\mathrm{Al}, 3: 1)$.

material. The material was found mesoporous with the surface area $90 \mathrm{~m}^{2} \mathrm{~g}^{-1}$.

A total mass $38.26 \%$ at $330-570{ }^{\circ} \mathrm{C}$ in TG graph (Fig. 5) of hydrotalcite $\left(\mathrm{Al}: \mathrm{Mg}: \mathrm{CO}_{3}\right)$ and other mass loss at $60-230{ }^{\circ} \mathrm{C}$, 230-330 ${ }^{\circ} \mathrm{C}$, and $570-670{ }^{\circ} \mathrm{C}$ respectively. The TG results point out that the hydrotalcite $\left(\mathrm{Al}: \mathrm{Mg}: \mathrm{CO}_{3}\right)$ is thermally stable up to $230{ }^{\circ} \mathrm{C} .{ }^{25}$ The second mass loss between 223 and $330{ }^{\circ} \mathrm{C}$ has been ascribed to the dehydroxylation of the brucite like layers along with anion decomposition leaving a $\mathrm{Mg}$, $\mathrm{Al}$ oxo-hydroxide up to $330{ }^{\circ} \mathrm{C}$. Finally third mass loss has been assigned to progressive elimination of hydroxyl ions and produce metal oxides and spinel structure.

The Ca : Al metal ratio was found in good agreement with the initially taken metallic ratio. The observed value for $\mathrm{Ca}-\mathrm{Al}-\mathrm{CO}_{3}$ was $3: 2: 1$. The P-XRD patterns for the LDHs $\mathrm{Ca}-\mathrm{Al}-\mathrm{CO}_{3}$ exhibits features commonly shown by layered materials. There are narrow, symmetric, strong lines at low $2 \theta$ values and weaker, less symmetric lines at high $2 \theta$ value (Fig. 6). ${ }^{26}$ Presence of $\mathrm{CO}_{3}{ }^{2-}$ 


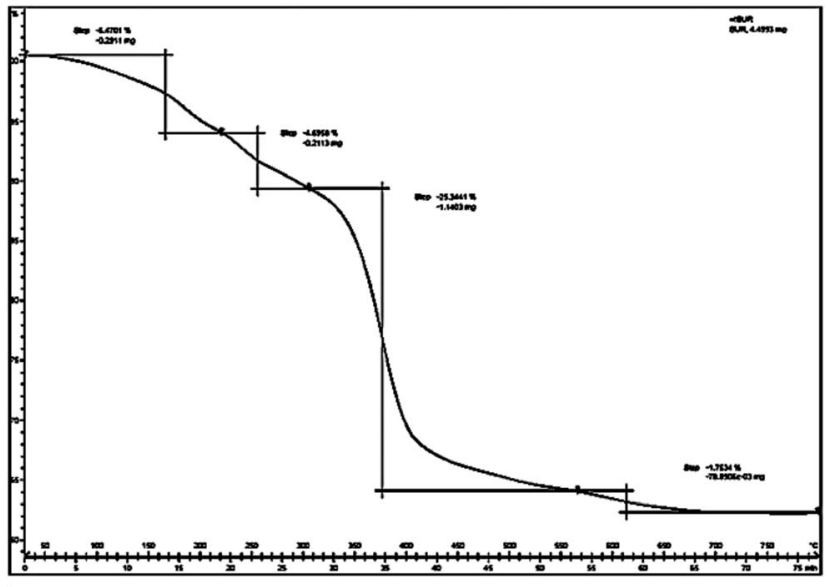

Fig. 5 DTG curve of hydrotalcite $(\mathrm{Mg}-\mathrm{Al} ; 3: 1)$.

anion in the interlayer gallery of the hydrotalcite is confirmed by the characteristic basal spacing $d_{003}=3.38 \AA$. Sharp intense peaks at low diffraction angles (peaks close to $2 \theta=11^{\circ}, 24^{\circ}$, and $35^{\circ}$; ascribed to diffraction by basal planes (003), (006), and (009), respectively) and broad, less intense peaks at higher angles (peaks close to $2 \theta=38^{\circ}, 46^{\circ}$, and $60^{\circ}$ ) ascribed to diffraction by (105), (108) and (110) planes confirm the presence of hydrotalcite. The crystallite size of this sample was found $47.025 \mathrm{~nm}$. SEM (Fig. 6) of the material shows high crystallinity. The particles of hydrotalcite $\mathrm{Ca}-\mathrm{Al}-\mathrm{CO}_{3}$ clearly exhibit the hexagonal shape; however, big needle shape particles are also visible.

\section{Chemistry}

To optimize the reaction conditions, a model reaction of 4hydroxy coumarin, benzaldehyde and 2-aminobenzothiazole was carried under solvent free conditions. Under room temperature (Table 1, entry 1), reaction was slow and yield of target product was too low, even reaction has performed at 90 and $120^{\circ} \mathrm{C}$ (Table 1, entries 4 and 5). Best yield was obtained at $70{ }^{\circ} \mathrm{C}$ with minimum time $(3.0 \mathrm{~h})$. So, $70{ }^{\circ} \mathrm{C}$ temperature was choose for further study. As shown in Fig. 2, the reactions of 1,2phenylenediamine with benzaldehyde (Scheme 1), 2-aminothiophenol with benzaldehyde (Scheme 2), and 2-aminophenol with benzaldehyde (Scheme 3) were selected as model reactions to investigate catalytic activity of hydrotalcite under solvent free conditions. To optimize the reaction conditions, variety of catalysts were screened in a model reaction of $o$-phenylenediamine and benzaldehyde and results are summarized in Table 2. This clearly indicates that in the absence of catalyst, reaction did not work beneficially (Table 2, entry 1 ). From Table 2 , it has been found that best yield was obtained with hydrotalcite (HT, $\mathrm{Mg}-\mathrm{Al}-\mathrm{CO}_{3}$ ) with lower time as compared to other catalysts. Further to identify the catalyst loading, different amount of loading (Table 2, entries 2-5) was used and $20 \mathrm{mg}$ of catalyst (HT) was suitable to promote the reaction efficiently (Table 2, entry 4). An increment in catalyst concentration more than $20 \mathrm{mg}$ did not show effective improvement in product yield (Table 2, entry 5). Slightly lower yield was obtained with $\mathrm{Ca}-\mathrm{Al}-$
$\mathrm{CO}_{3}$ hydrotalcite (Table 2, entry 6) as compared to $\mathrm{Mg}-\mathrm{Al}-\mathrm{CO}_{3}$ hydrotalcite. Other metal oxide, hydroxide and chlorides give moderate yield of final product (Table 2, entries 7-13).

Recyclability of the catalyst is an important task in industrial applications. Therefore reusability of hydrotalcite $\left(\mathrm{Mg}-\mathrm{Al}-\mathrm{CO}_{3}\right)$ was investigated for eight runs (Table 3, entries 2-9) in a model reaction of benzaldehyde and $o$-phenylenediamine by incorporating $20 \mathrm{mg}$ of hydrotalcite as catalyst (Fig. 7). After completion of reaction, the contents were filtered to recycle the hydrotalcite catalyst. Recycled hydrotalcite washed with methanol to remove organic impurities. $\mathrm{Mg}^{\mathrm{II}}$ hydrotalcite catalyst can be readily recovered and reused for eight runs. It was found that the reactivity of the catalyst decreases marginally (approx. 9-10\%) for the eight runs.

To generalize the applicability and scope of this protocol in the formation of functionalized heterocycles were investigated by using various substituted aldehydes. Different electron donating and electron withdrawing aldehydes were used and as expected it give good yield of target products, it can be seen that electron donating and electron withdrawing groups does not show any significant difference on the reaction yields (Tables 4-6). This indicated that present catalytic system efficiently makes the condensation reaction much faster with increased yields.

\section{Leaching test}

Filtrate was analyzed for leached metal content by ICP emission spectroscopy. No metal was detected. These results confirmed that the metal leaching did not occur. However, Mg-Al mixed oxide was found to be thermally and mechanically stable and no significant difference was observed in particle size and morphology of the used catalyst as evidenced by SEM. ${ }^{27}$ To ensue the sustainability of structure of recovered hydrotalcite, XRD has been carried out which showed the similar profile as fresh catalyst which confirmed that layered structure of hydrotalcite was maintained after the reaction.

\section{Effect of aging time and SEM analysis}

To observe the effect of aging time on the morphology of the material, SEM images of hydrotalcite samples at $\mathrm{Mg} / \mathrm{Al}$ molar ratio of 3.0 were recorded. The micrographs at different aging times are shown in Fig. 8. Micrographs of hydrotalcite show a well-developed layered and platelet structure of the hydrotalcite. However, a spongy type structure is exhibited due to overlapping of such platelets. The SEM images of the hydrotalcite showed a gradual crystallization during the hydrothermal treatment conditions. At the temperature $110{ }^{\circ} \mathrm{C}$ (hydrothermal treatment temperature) and $0 \mathrm{~h}$ aging time, crystallinity of the hydrotalcite was observed to be very poor; however, as aging time increases from 0 to $10 \mathrm{~h}$, the crystallinity of the hydrotalcite also increased. These results confirmed an increase in the crystallinity of the hydrotalcite samples at $\mathrm{Mg} / \mathrm{Al}$ under hydrothermal treatment conditions.

\section{Basicity of hydrotalcite}

Basicity of the catalyst was determined using Hammett indicator and benzoic acid titration method. ${ }^{28}$ All samples prepared 


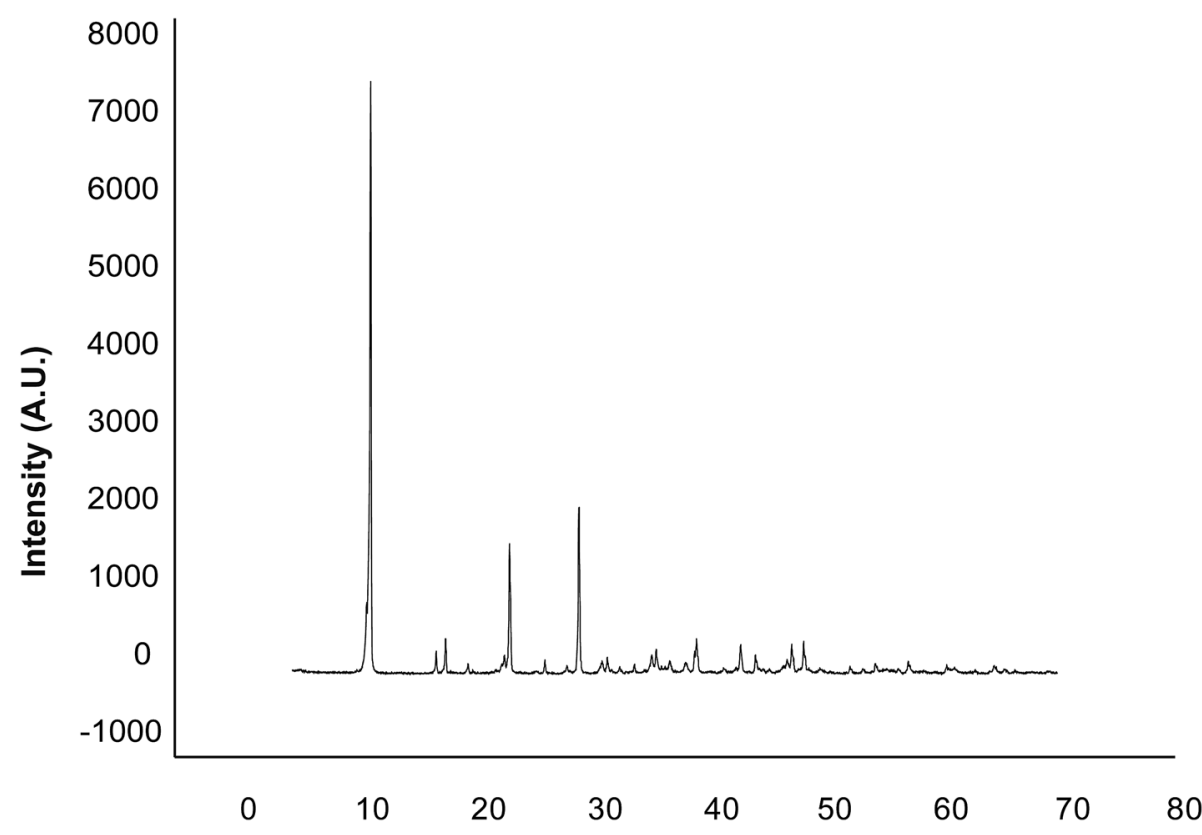

XRD Pattern (Ca-Al-3:1)

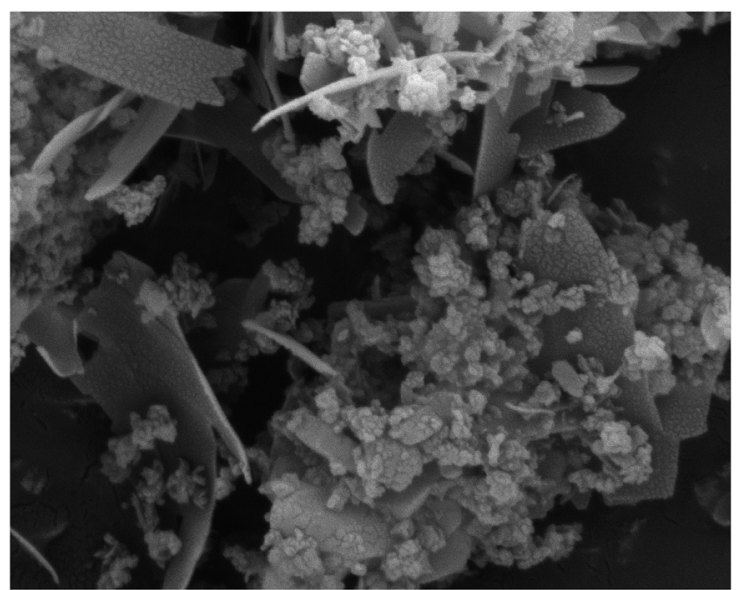

SEM Image (Ca-Al- 3:1)

Fig. 6 P-XRD and pattern and SEM image of hydrotalcite (Ca-Al, $3: 1)$.

Table 1 Optimization of reaction temperature ${ }^{a}$

\begin{tabular}{llll}
\hline Entry & Time $(\mathrm{h})$ & Temperature $\left({ }^{\circ} \mathrm{C}\right)$ & Yield\% of $\mathbf{3 a}{ }^{b}$ \\
\hline 1 & 5.0 & $\mathrm{RT}^{c}$ & 20 \\
2 & 5.0 & 50 & 60 \\
3 & 3.0 & 70 & 95 \\
4 & 3.0 & 90 & 95 \\
5 & 3.0 & 120 & 93
\end{tabular}

${ }^{a}$ Reaction conditions: benzaldehyde $(1.0 \mathrm{mmol}), o$-phenylenediamine $(1.0 \mathrm{mmol})$, hydrotalcite $(20 \mathrm{mg})$, at $70{ }^{\circ} \mathrm{C} .{ }^{b}$ Isolated yield. ${ }^{c} \mathrm{RT}=$ room temperature. in our study had the basic strength in the range of 9.3-15.0. The basicity of the catalysts with different $\mathrm{Mg} / \mathrm{Al}$ molar ratios was shown in Fig. 9. The main basic sites with $\mathrm{H}_{-}$in the range of 7.2-9.8 and the other sites with $\mathrm{H}_{-}$in the range of 9.8-15.0 were observed, thus suggesting the calcined hydrotalcites contain different types of surface basic sites. Di Cosimo et al. ${ }^{29}$ suggested that pure $\mathrm{MgO}$ possesses strong basic sites consisting predominantly of $\mathrm{O}^{2-}$ and calcined hydrotalcites contain surface basic sites. Our experimental results on the Hammett titration method conform to this viewpoint. It indicates a wide basic site distribution as far as the basicity is concerned. 
Table 2 Optimization of reaction conditions ${ }^{a}$

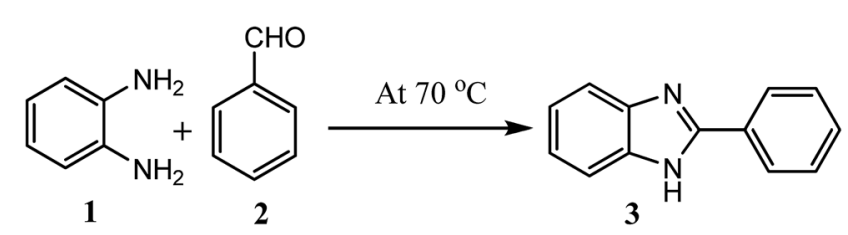

\begin{tabular}{llll}
\hline Entry & Catalyst (in grams) & Time $(\mathrm{h})$ & ${\text { Yield\% of } 3 \mathrm{a}^{b}}^{b}$ \\
\hline 1 & No catalyst & 6.0 & 25 \\
2 & $\mathrm{Mg}-\mathrm{Al}-\mathrm{CO}_{3}, \mathrm{HT}(0.005)$ & 6.0 & 75 \\
3 & $\mathrm{Mg}-\mathrm{Al}-\mathrm{CO}_{3}, \mathrm{HT}(0.01)$ & 4.0 & 88 \\
4 & $\mathrm{Mg}-\mathrm{Al}-\mathrm{CO}_{3}, \mathrm{HT}(0.02)$ & 3.0 & 95 \\
5 & $\mathrm{Mg}-\mathrm{Al}-\mathrm{CO}_{3}, \mathrm{HT}(0.05)$ & 3.0 & 95 \\
6 & $\mathrm{Ca}-\mathrm{Al}-\mathrm{CO}_{3}, \mathrm{HT}(0.02)$ & 2.0 & 89 \\
7 & $\mathrm{AlCl}_{3}(0.02)$ & 5.0 & 59 \\
8 & $\mathrm{SiO}_{2}(0.02)$ & 4.0 & 72 \\
9 & $\mathrm{MnO}_{2}(0.02)$ & 4.0 & 61 \\
10 & $\left.\mathrm{Al}^{(\mathrm{OH}}\right)_{3}(0.02)$ & 4.5 & 50 \\
11 & $\mathrm{Ca}(\mathrm{OH})_{2}(0.02)$ & 4.0 & 51 \\
12 & $\mathrm{Al}_{2} \mathrm{O}_{3}(0.02)$ & 4.5 & 60 \\
13 & $\mathrm{Mg}(\mathrm{OH})_{2}(0.02)$ & 4.5 & 42
\end{tabular}

${ }^{a}$ Reaction conditions: benzaldehyde $(1 \mathrm{mmol}), o$-phenylenediamine $(1$ $\mathrm{mmol})$, hydrotalcite $(20 \mathrm{mg})$, at $70{ }^{\circ} \mathrm{C} .{ }^{b}$ Isolated yield.

Table 3 Recyclability of hydrotalcite $\left(\mathrm{Mg}-\mathrm{Al}-\mathrm{CO}_{3}\right)$ in model reaction

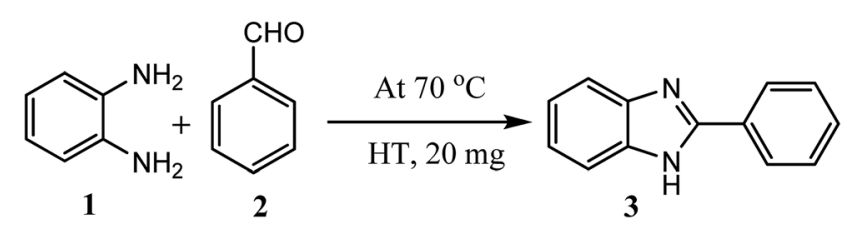

\begin{tabular}{lll}
\hline Entry & No. of runs & Yield\% of $\mathbf{3 a}^{a}$ \\
\hline 1 & 0 & 95 \\
2 & 1 & 93 \\
3 & 2 & 91 \\
4 & 3 & 89 \\
5 & 4 & 88 \\
6 & 5 & 88 \\
7 & 6 & 86 \\
8 & 7 & 86 \\
9 & 8 & 85 \\
${ }^{a}$ Isolated yield. & &
\end{tabular}

As molar ratio of $\mathrm{Mg} / \mathrm{Al}$ reach up to the maximum value 3.0, the total basicity of the hydrotalcite (catalyst) was increased gradually. But basicity was decreased when further increase the molar ratio of $\mathrm{Mg} / \mathrm{Al}$, which resulted in a loss of the catalytic activity. Qualitatively similar trends were also reported by other researchers. $^{30}$ Nakatsuka et $a .^{30 a}$ found that the basicity measured by titration with benzoic acid reached a maximum for $\mathrm{Mg} / \mathrm{Al}$ ratio of about 2.6. Also, Fishel and Davis ${ }^{30 b}$ measured the number of basic sites by TPD of $\mathrm{CO}_{2}$ and a maximum of the basic site density was observed at $\mathrm{Mg} / \mathrm{Al}$ ratio of 3.0. Best results

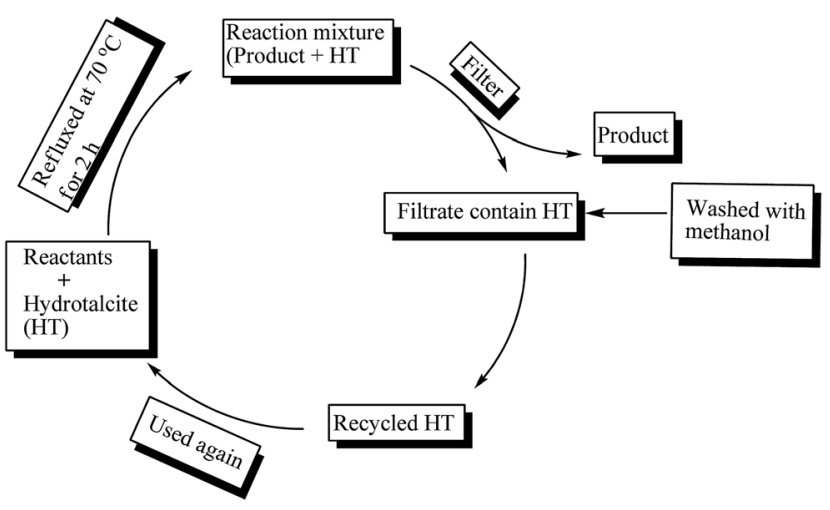

Fig. 7 Recyclability and reusability of hydrotalcite catalyst.

were obtained with 3.0 HT, therefore basicity of 3.0 HT calcined at different temperatures was measured with the same method; the results are illustrated in Fig. 10. From this figure, it can be seen that the maximum basicity (reaching $3.6 \mathrm{mmol} \mathrm{g}^{-1}$ ) is found at a calcinations temperature of $750 \mathrm{~K}$ and a low level of basicity is observed below $573 \mathrm{~K}$ and above $750 \mathrm{~K}$. The increased basicity could be expected to correlate with an increase of the catalyst activity.

\section{Conclusion}

In conclusion, we have developed green methodology for synthesis of hydrotalcite by grinding method. Prepared hydrotalcite could be used efficiently in selective, eco-friendly and green synthesis for variety of substituted benzimidazoles, benzothiazoles and benzoxazoles from 1,2-phenylenediamine, 2aminothiophenol, and 2-aminophenol with substituted aromatic aldehydes under solvent free conditions. The catalytic activities of the calcined hydrotalcite show a striking correlation with their corresponding basic properties. The prepared catalyst were characterized with Hammett titration method, SEM, TG, IR and XRD showing the strong basic sites in double layers and coordinatively unsaturated $\mathrm{O}^{2-}$ ion acting as basic sites in the calcined hydrotalcite may be responsible for their catalytic activity. The crystallization of hydrotalcite was significantly affected by hydrothermal treatment temperature and time.

This is first attempt to synthesize substituted benzimidazoles, benzothiazoles and benzoxazoles using hydrotalcite as heterogeneous catalyst which is easily separable and recyclable up to eight runs. Compared to previously reported methods, moreover, the mild reaction conditions, easy work-up, clean reaction profiles, lower catalyst loading and cost efficiency render this approach as an interesting alternative to the existing methods.

\section{Materials and methods}

\section{Experimental}

The ${ }^{1} \mathrm{H}$ NMR spectra were measured using BRUKER AVANCE II 400 NMR spectrometer with tetramethylsilane as an internal standard at $20-25{ }^{\circ} \mathrm{C}$; data for ${ }^{1} \mathrm{H}$ NMR are reported as follows: 
Table 4 Hydrotalcite catalyzed synthesis of benzimidazole derivatives ${ }^{a}$

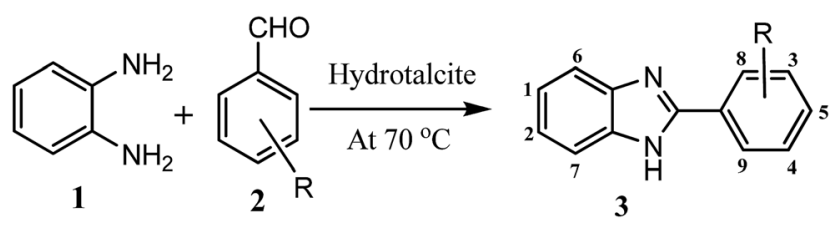

\begin{tabular}{|c|c|c|c|c|c|c|}
\hline \multirow[b]{2}{*}{$\mathrm{R}$} & \multirow[b]{2}{*}{ Product } & \multirow[b]{2}{*}{ Yield (\%) } & \multirow[b]{2}{*}{ Time (h) } & \multicolumn{3}{|l|}{$\mathrm{MP}\left({ }^{\circ} \mathrm{C}\right)$} \\
\hline & & & & Found & Reported & Ref. \\
\hline $\mathrm{H}$ & & 95 & 3.0 & $290-291$ & $290-293$ & $7 f$ \\
\hline $4-\mathrm{NO}_{2}$ & & 91 & 2.5 & $321-323$ & $322-323$ & $7 \mathrm{f}$ \\
\hline $4-\mathrm{OH}$ & & 90 & 2.0 & $277-279$ & $265-267$ & $7 \mathrm{~h}$ \\
\hline $2-\mathrm{OH}$ & & 93 & 2.5 & $222-224$ & $236-237$ & $7 \mathrm{n}$ \\
\hline $4-\mathrm{Cl}$ & & 92 & 2.0 & $288-291$ & $288-291$ & $7 \mathrm{~g}$ \\
\hline $4-\mathrm{OCH}_{3}$ & & 96 & 2.0 & $221-223$ & 180-182 & $7 \mathrm{i}$ \\
\hline $4-\mathrm{CH}_{3}$ & & 95 & 2.0 & $260-262$ & $264-265$ & $7 \mathrm{f}$ \\
\hline
\end{tabular}

${ }^{a}$ Reaction conditions: aldehydes $(1 \mathrm{mmol}), o$-phenylenediamine $(1 \mathrm{mmol})$, hydrotalcite $(20 \mathrm{mg})$, at $70{ }^{\circ} \mathrm{C}$ temp.

chemical shift (ppm), integration, multiplicity (s, singlet; $d$, doublet; t, triplet; q, quartet; m, multiplet, and br, broad), coupling constant $(\mathrm{Hz})$. IR spectra were recorded by SHIMADZU; IR spectrometer of sample dispersed in $\mathrm{KBr}$ pellet or Nujol is reported in terms of frequency of absorption $\left(\mathrm{cm}^{-1}\right)$. E-
Merck pre-coated TLC plates and RANKEM silica gel G were used for preparative thin-layer chromatography. Melting points were determined in open capillaries and are uncorrected. AR grade of $o$-phenylenediamine, 2-aminothiophenol, 2-aminophenol, aldehydes and other catalysts were purchased from 
Table 5 Hydrotalcite catalyzed synthesis of benzothiazole derivatives ${ }^{a}$

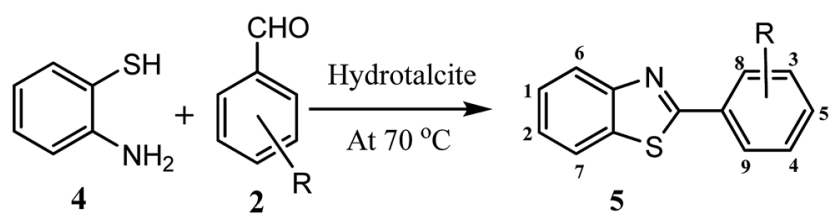

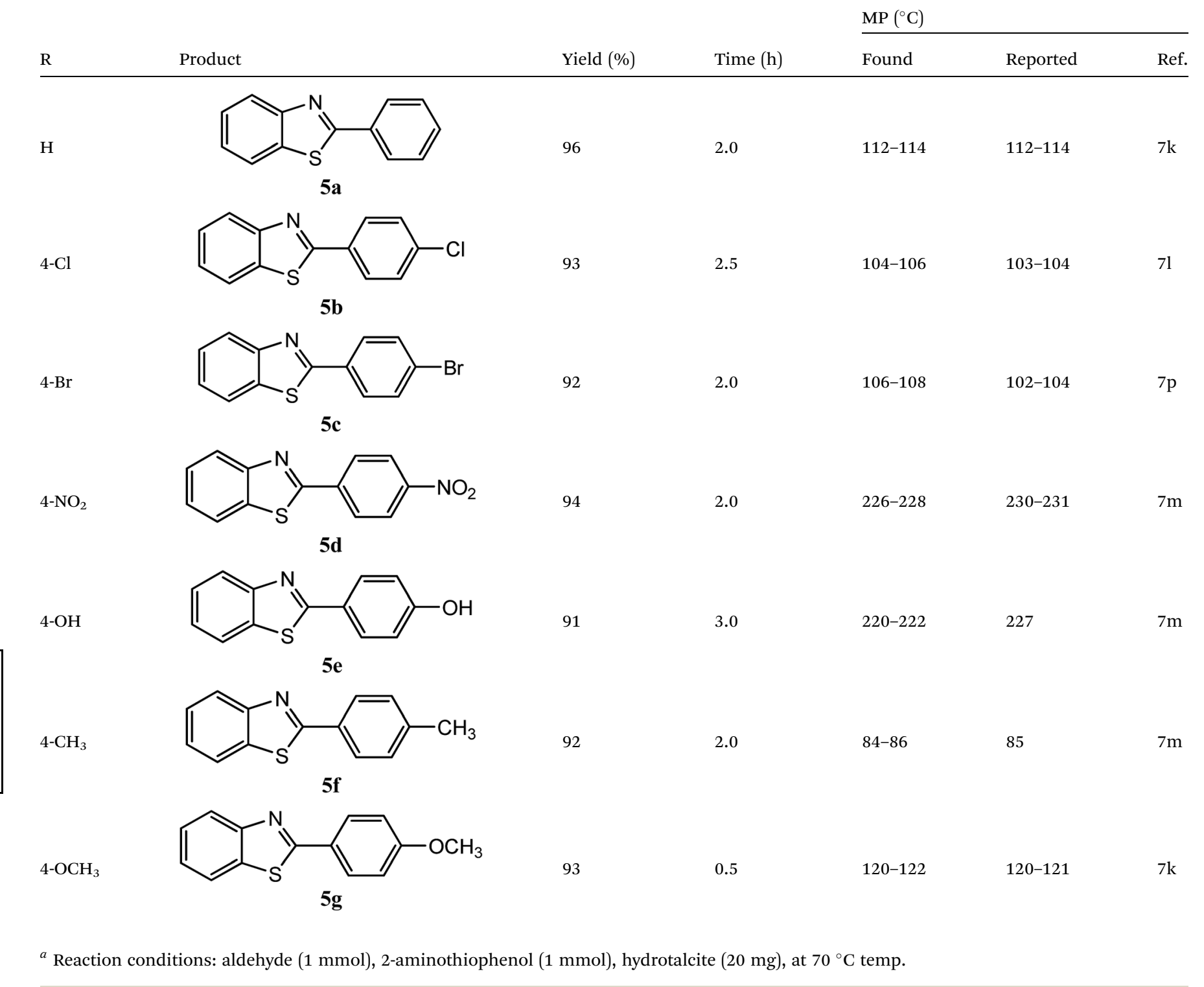

Himedia Laboratory Ltd., Mumbai, India and used without further purification.

\section{Preparation of hydrotalcite (HT)}

Typical procedure. $\mathrm{Al}_{2} \mathrm{O}_{3}(1.02 \mathrm{~g})$ was suspended in distilled water $(2 \mathrm{ml})$ and magnesium hydroxide $(3.5 \mathrm{~g})$ was added to the mixture and the contents were stirred giving the $\mathrm{pH}$ of 8 . Then sodium bicarbonate $(2.4 \mathrm{~g})$ was added to bring the $\mathrm{pH}$ of the mixture at 10. The mixture was ground in mortar-pestle for $5 \mathrm{~min}$ at room temperature and the resulting white product was filtered and repeatedly washed with distilled water and dried at $100{ }^{\circ} \mathrm{C}$.

Typical procedure for synthesis of benzimidazoles, benzothiazoles and benzoxazoles. A mixture of aldehydes (1 mmol) and $o$-phenylenediamine, 2-aminothiophenol, or 2-aminophenol (1 mmol) was heated at $70{ }^{\circ} \mathrm{C}$ under solvent free conditions using hydrotalcite $(20 \mathrm{mg})$ as a catalyst. After completion of the reaction (by TLC analysis), the reaction mixture was cooled to room temperature and poured in cold water. Then the solid mass obtained was dissolved in ethanol and filtered. The solid hydrotalcite got separated as solid. 
Table 6 Hydrotalcite catalyzed synthesis of benzoxazole derivatives ${ }^{a}$

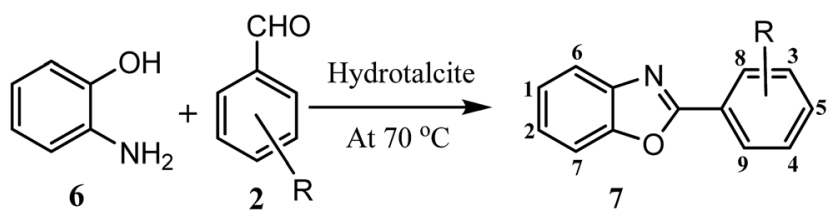

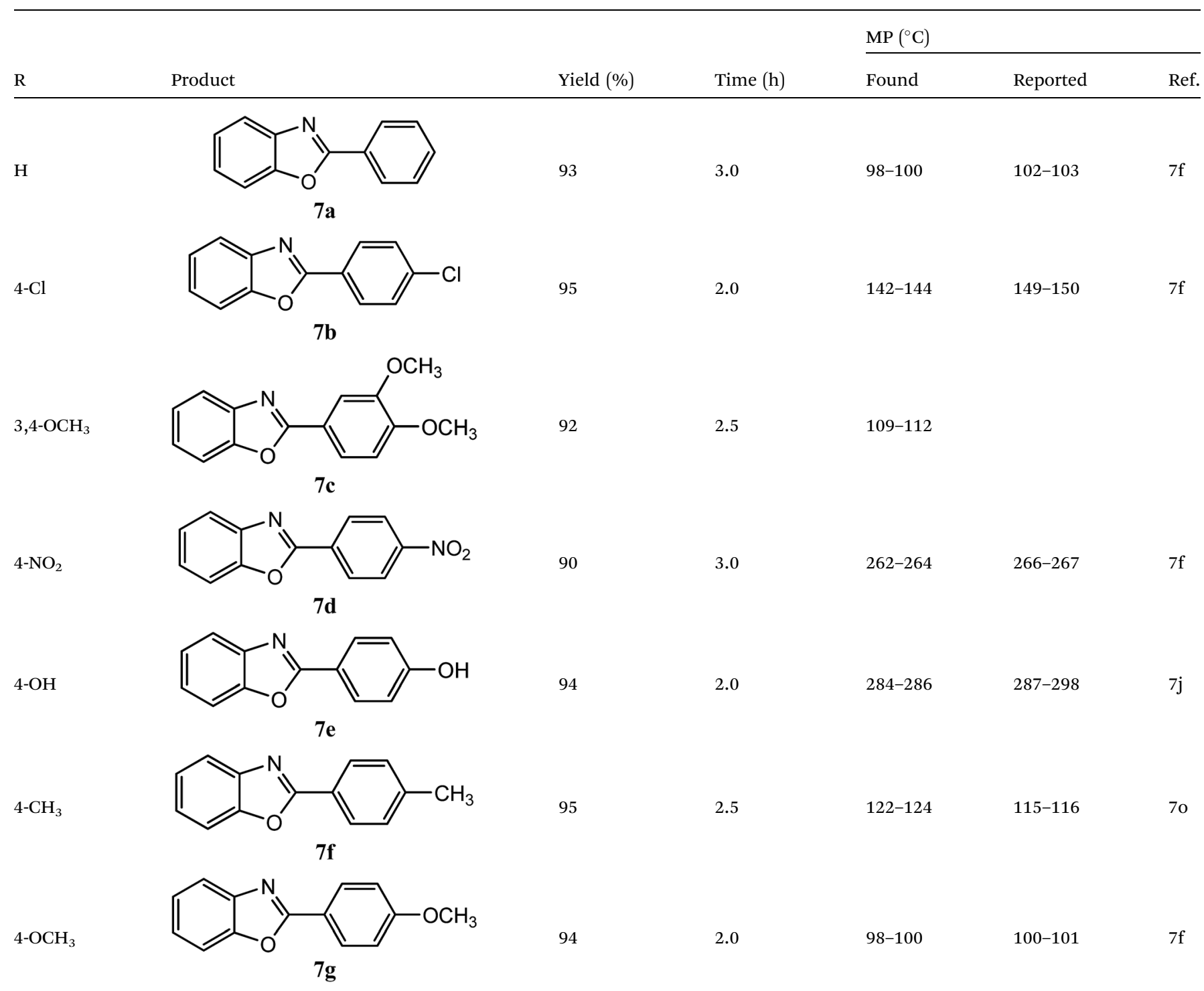

${ }^{a}$ Reaction conditions: aldehyde $(1 \mathrm{mmol}), 2$-aminophenol $(1 \mathrm{mmol})$, hydrotalcite $(20 \mathrm{mg})$, at $70{ }^{\circ} \mathrm{C}$ temp.

Product was recrystallized in ethanol. Hydrotalcite was washed with ethanol to remove organic impurity and dried.

\section{Characterization}

2-Phenyl-1H-benzimidazole 3a. Mp 290-291 ${ }^{\circ} \mathrm{C} ; R_{\mathrm{f}}=0.5$; ESIMS $(m / z)=193(\mathrm{M}-1) ;{ }^{1} \mathrm{H}-\mathrm{NMR}\left(400 \mathrm{MHz}, \mathrm{DMSO}_{6}\right), 12.79(\mathrm{~s}$, $1 \mathrm{H}, \mathrm{NH}), 8.19$ (d, 2H, ArH-8, 9, $J=4.0 \mathrm{~Hz}), 7.59-7.57(\mathrm{~m}, 2 \mathrm{H}$, ArH-6, 7), 7.53-7.44 (m, 3H, ArH-3, 4, 5), 7.21-7.17 (m, 2H, ArH1, 2); ${ }^{13} \mathrm{C}-\mathrm{NMR}$ (75.45 MHz, DMSO) 110.0, 119.2, 122.1, 122.6, 126.3, 129.7, 130.1, 135.8, 136.8, 142.6, 151.1 .
2-(4-Nitrophenyl)- $1 \boldsymbol{H}$-benzimidazole $3 \mathrm{~b} . \mathrm{Mp} 321-323^{\circ} \mathrm{C} ; R_{\mathrm{f}}=$ 0.45; ESI-MS $(m / z)=240(\mathrm{M}+1) ;{ }^{1} \mathrm{H}-\mathrm{NMR}\left(400 \mathrm{MHz}, \mathrm{DMSO}_{\mathrm{d}}\right)$, 13.07 (s, 1H, NH), 8.45 (d, 2H, ArH-3, 4, J=8.96 Hz), 8.37 (d, 2H, ArH-8, 9, $J=8.88 \mathrm{~Hz}$ ), 7.64 (s, 2H, ArH-4, 5), 7.27 (d, 2H, ArH-1, $2, J=7.76 \mathrm{~Hz}) ;{ }^{13} \mathrm{C}-\mathrm{NMR}(75.45 \mathrm{MHz}$, DMSO) 111.7, 119.4, 122.3, 123.5, 124.1, 127.3, 135.2, 135.9, 143.8, 147.6, 148.9.

2-(4-Hydroxyphenyl)-1H-benzimidazole $3 \mathrm{c}$. Mp $277-280{ }^{\circ} \mathrm{C}$; $R_{\mathrm{f}}=0.55$; ESI-MS $(\mathrm{m} / \mathrm{z})=209(\mathrm{M}-1)$; ${ }^{1} \mathrm{H}-\mathrm{NMR}(400 \mathrm{MHz}$, DMSO-d $_{6}$ ), 9.78 (s, 1H, NH), 8.01 (t, 2H, ArH-8, 9, $J=8.44 \mathrm{~Hz}$ ), 7.54-7.52 (m, 2H, ArH-6, 7), 7.20-7.14 (m, 2H, ArH-3, 4), 6.91 (d, 


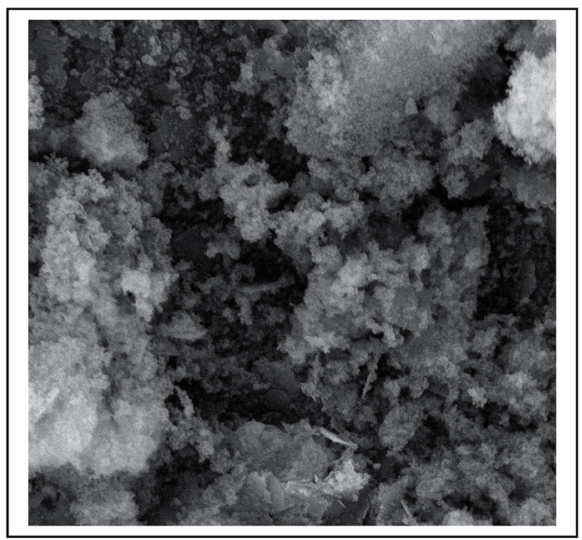

$\mathrm{T}=110{ }^{\circ} \mathrm{C} ; \mathbf{0 ~ h}$

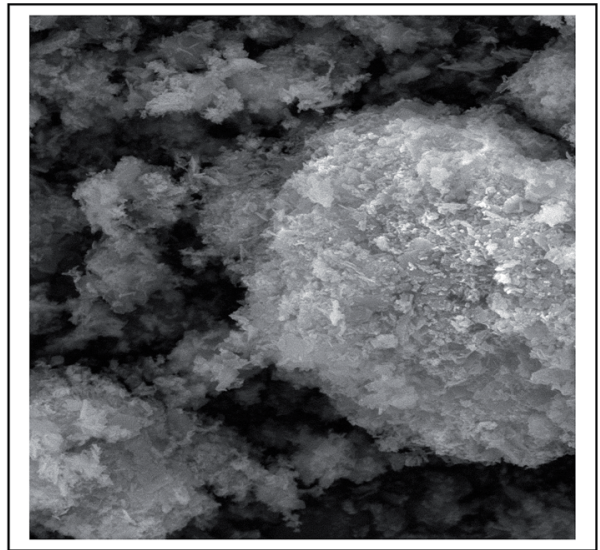

$\mathrm{T}=110^{\circ} \mathrm{C} ; 6_{\mathrm{h}}$

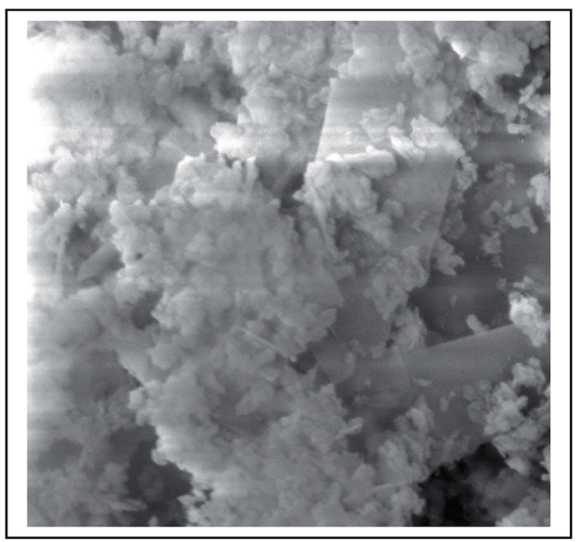

$\mathrm{T}=110{ }^{\circ} \mathrm{C} ; 3 \mathrm{~h}$

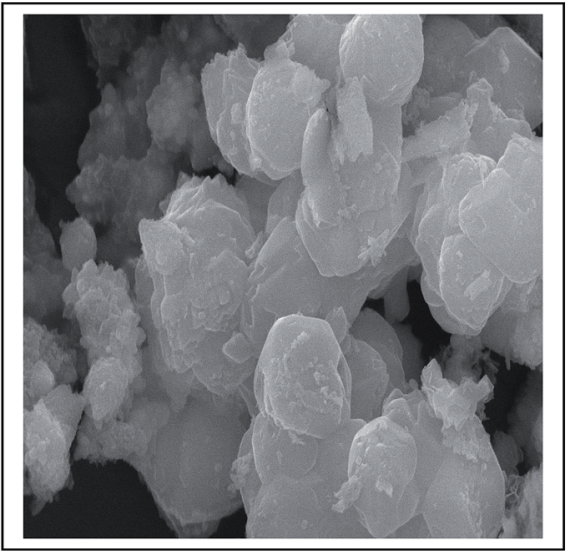

$\mathrm{T}=110{ }^{\circ} \mathrm{C} ; 9 \mathrm{~h}$

Fig. 8 SEM image of hydrotalcite at a $\mathrm{Mg} / \mathrm{Al}(3: 1)$ at different aging time at $110^{\circ} \mathrm{C}$.

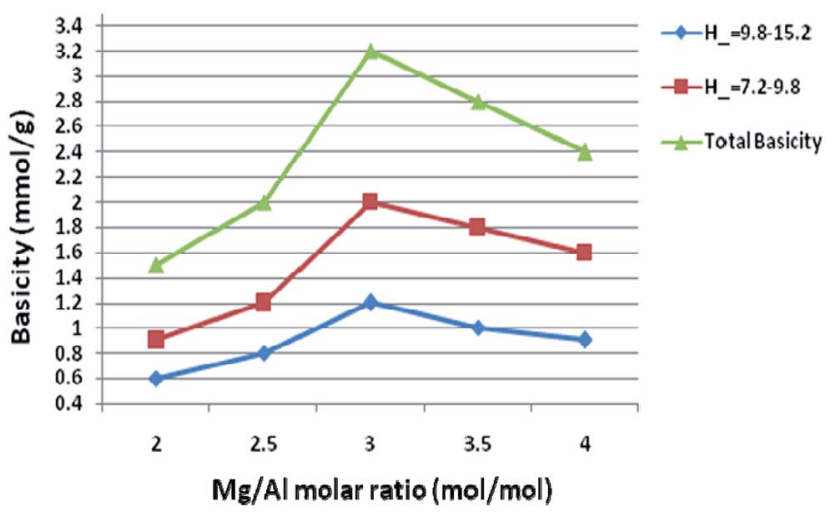

Fig. 9 Basicity of hydrotalcite with different metal ratios.

2H, ArH-1, 2, $J=8.40 \mathrm{~Hz}), 5.37$ (s, 1H, OH); ${ }^{13} \mathrm{C}-\mathrm{NMR}(75.45$ MHz, DMSO) 115.1, 122.1, 128.1, 128.6, 128.7, 128.9, 129.0, 130.7, 131.1, 134.5, 150.1 .

2-(2-Hydroxyphenyl)-1H-benzimidazole 3d. Mp 222-224 ${ }^{\circ} \mathrm{C}$; $R_{\mathrm{f}}=0.55$; ESI-MS $(\mathrm{m} / z)=209(\mathrm{M}-1)$; ${ }^{1} \mathrm{H}-\mathrm{NMR}(400 \mathrm{MHz}$, DMSO-d $_{6}$ ), 12.97 (s, 1H, NH), 8.21 (d, 2H, ArH-8, 9), 7.50-7.43 (m, 4H, ArH-6, 7, 1, 3, 4), 7.23 (d, 2H, ArH-1, 2, J=8.24 Hz), 5.52 (s, 1H, OH); ${ }^{13} \mathrm{C}-\mathrm{NMR}$ (75.45 MHz, DMSO) 116.6, 117.1, 119.0,

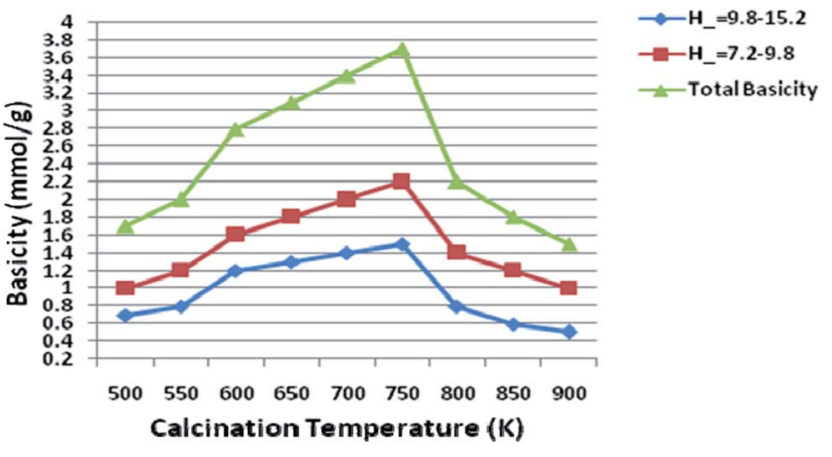

Fig. 10 Basicity of 3.0 hydrotalcite at different temperature.

$119.4,119.7,126.2,127.7,131.7,132.4,133.4,142.2,160.3$, 164.0 .

2-(4-Chlorophenyl)-1H-benzimidazole 3e. Mp 288-291 ${ }^{\circ} \mathrm{C} ; R_{\mathrm{f}}$ $=0.35$; ESI-MS $(\mathrm{m} / \mathrm{z})=229(\mathrm{M}+1) ;{ }^{1} \mathrm{H}-\mathrm{NMR}(400 \mathrm{MHz}$, DMSO$\left.\mathrm{d}_{6}\right), 12.91(\mathrm{~s}, 1 \mathrm{H}, \mathrm{NH}), 7.91$ (d, 2H, ArH-8, 9, J=8.32 Hz), 7.607.46 (m, 2H, ArH-6, 7), 6.98-7.11 (m, 2H, ArH-3, 4), 6.78-6.89 (m, 2H, ArH-1, 2); ${ }^{13} \mathrm{C}-\mathrm{NMR}$ (75.45 MHz, DMSO) 115.1, 122.3, $127.9,128.1,128.7,128.8,128.9,129.0,130.7,131.1,134.5$, 150.1 . 
2-(4-Methoxyphenyl)-1H-benzimidazole 3f. $\mathrm{Mp} 180-182{ }^{\circ} \mathrm{C}$; $R_{\mathrm{f}}=0.5$; ESI-MS $(\mathrm{m} / \mathrm{z})=225(\mathrm{M}+1) ;{ }^{1} \mathrm{H}$ NMR $(400 \mathrm{MHz}, \mathrm{DMSO}-$ $\left.\mathrm{d}_{6}\right): 12.93(\mathrm{~s}, 1 \mathrm{H}, \mathrm{NH}), 7.92(\mathrm{~d}, 2 \mathrm{H}, \operatorname{ArH}-8,9, J=8.0 \mathrm{~Hz}), 7.58-$ 7.75 (m, 1H, ArH-6), 7.48-7.55 (m, 1H, ArH-7), 7.22 (d, 2H, ArH$3,4, J=7.6 \mathrm{~Hz}$ ), 7.38-7.47 (m, 2H, ArH-1, 2), 3.81 (s, 3H, $\left.\mathrm{OCH}_{3}\right)$; ${ }^{13} \mathrm{C}$ NMR (75.45 MHz, DMSO-d ${ }_{6}$ ): 55.6, 114.6, 115.3, 121.4, 123.0, 123.2, 128.5, 130.2, 138.7, 152.8, 160.7.

2-(4-Methylphenyl)-1H-benzimidazole 3g. Mp $260-262{ }^{\circ} \mathrm{C} ; R_{\mathrm{f}}$ $=0.55$; ESI-MS $(\mathrm{m} / \mathrm{z})=209(\mathrm{M}+1)$; ${ }^{1} \mathrm{H}-\mathrm{NMR}(400 \mathrm{MHz}$, DMSO$\left.\mathrm{d}_{6}\right), 9.78(\mathrm{~s}, 1 \mathrm{H}, \mathrm{NH}), 8.11(\mathrm{t}, 2 \mathrm{H}, \mathrm{ArH}-8,9, J=11.04 \mathrm{~Hz}), 7.57-$ 7.55 (m, 2H, ArH-6, 7), 7.32 (d, 2H, ArH-3, 4, J=7.88 Hz), 7.197.15 (m, 2H, ArH-1, 2), 2.41 (s, 3H, $\left.\mathrm{CH}_{3}\right) ;{ }^{13} \mathrm{C}-\mathrm{NMR}(75.45 \mathrm{MHz}$, DMSO) 20.9, 121.9, 126.4, 127.4, 129.3, 129.4, 130.1, 132.2, 139.5, 150.1, 161.11 .

2-Phenyl-benzothiazole 5a. Mp $112-114{ }^{\circ} \mathrm{C} ; R_{\mathrm{f}}=0.65$; ESI-MS $(m / z)=212(\mathrm{M}+1) ;{ }^{1} \mathrm{H}$ NMR $\left(400 \mathrm{MHz}, \mathrm{DMSO}_{-} \mathrm{d}_{6}\right): 8.07-8.11(\mathrm{~m}$, $3 \mathrm{H}, \operatorname{ArH}-8,9,6), 7.91$ (d, 1H, ArH-7, $J=7.36 \mathrm{~Hz}), 7.48-7.52(\mathrm{~m}$, $4 \mathrm{H}, \mathrm{ArH}-1,2,3,4), 7.39$ (t, 1H, ArH-5, $J=8.0 \mathrm{~Hz}) ;{ }^{13} \mathrm{C}$ NMR (75.45 MHz, DMSO-d ${ }_{6}$ ): 120.9, 124.3, 125.41, 126.41, 127.92, 130.23, 131.67, 133.89, 143.25, 154.78, 168.24.

2-(4-Chlorophenyl)-benzothiazole 5b. Mp 104-106 ${ }^{\circ} \mathrm{C} ; R_{\mathrm{f}}=$ 0.55; ESI-MS $(m / z)=246(\mathrm{M}+1) ;{ }^{1} \mathrm{H}$ NMR (400 MHz, DMSO-d $\left.{ }_{6}\right)$ : 8.31-8.48 (m, 2H, ArH-8, 9), 7.40-7. 81 (m, 1H, ArH-6), 7.62 (d, $2 \mathrm{H}, \mathrm{ArH}-3,4, J=7.6 \mathrm{~Hz}), 7.48-7.56(\mathrm{~m}, 1 \mathrm{H}, \mathrm{ArH}-7), 7.24(\mathrm{~d}, 2 \mathrm{H}$, ArH-1, $2, J=8.26 \mathrm{~Hz}$ ); ${ }^{13} \mathrm{C}$ NMR (75.45 MHz, DMSO-d 6 ): 121.8, 125.2 , 126.50, 127.52, 128.82, 131.31, 132.67, 134.69, 145.25, 155.78, 167.94 .

2-(4-Bromophenyl)-benzothiazole 5c. $\mathrm{Mp} 106-108{ }^{\circ} \mathrm{C} ; R_{\mathrm{f}}=$ 0.45; ESI-MS $(\mathrm{m} / \mathrm{z})=290\left(\mathrm{M}^{+}\right) ;{ }^{1} \mathrm{H}$ NMR (400 MHz, DMSO-d $\left.{ }_{6}\right)$ : 8.26-8.32 (m, 2H, ArH-8, 9), 7.48-7.88 (m, 1H, ArH-6), 7.64 (d, $2 \mathrm{H}, \mathrm{ArH}-3,4, J=7.56 \mathrm{~Hz}$ ), 7.50-7.58 (m, 1H, ArH-7), 7.31 (d, 2H, ArH-1, $2, J=8.26 \mathrm{~Hz}$ ); ${ }^{13} \mathrm{C}$ NMR (75.45 MHz, DMSO-d 6 ): 121.0, $125.1,126.2$, 127.1, 128.2, 131.3, 132.6, 134.6, 145.5, 155.0, 167.4 .

2-(4-Nitrophenyl)-benzothiazole $5 \mathrm{~d}$. $\mathrm{Mp} 226-228{ }^{\circ} \mathrm{C} ; R_{\mathrm{f}}=0.4$; $\operatorname{ESI-MS}(\mathrm{m} / \mathrm{z})=256(\mathrm{M}+1) ;{ }^{1} \mathrm{H}$ NMR $\left(400 \mathrm{MHz}, \mathrm{DMSO}^{-\mathrm{d}_{6}}\right): 8.28-$ 8.44 (m, 2H, ArH-8, 9), 7.48-7.98 (m, 1H, ArH-6), 7.62 (d, 2H, ArH-3, 4, J = 7.6 Hz), 7.45-7.53 (m, 1H, ArH-7), 7.25 (d, 2H, ArH$1,2, J=8.26 \mathrm{~Hz}) ;{ }^{13} \mathrm{C}$ NMR (75.45 MHz, DMSO-d 6 ): 120.09, 124.12, 125.25, 126.05, 128.08, 131.09, 132.60, 134.36, 145.05, 155.88, 167.99.

2-(4-Hydroxyphenyl)-benzothiazole 5e. $\mathrm{Mp} 220-222^{\circ} \mathrm{C} ; R_{\mathrm{f}}=$ 0.6; ESI-MS $(m / z)=228(\mathrm{M}+1) ;{ }^{1} \mathrm{H}$ NMR (400 MHz, DMSO-d $\left.{ }_{6}\right)$ : 10.23 (s, 1H, -OH), 8.08 (d, 1H, ArH-8, J=7.8 Hz), 7.92-7.99 (m, $3 \mathrm{H}, \mathrm{ArH}-6,7,9), 7.50$ (t, 1H, ArH-2, $=7.56 \mathrm{~Hz}$ ), 7.40 (t, 1H, ArH$1, J=7.36 \mathrm{~Hz}), 6.93(\mathrm{~d}, 2 \mathrm{H}, \mathrm{ArH}-3,4, J=8.4 \mathrm{~Hz}) ;{ }^{13} \mathrm{C}$ NMR $(75.45$ MHz, DMSO-d ${ }_{6}$ ) 116.1, 122.1, 122.3, 124.0, 124.9, 126.5, 129.1, 134.1, 153.7, 160.6, 167.5.

2-(4-Methylphenyl)-benzothiazole 5f. $\mathrm{Mp} 84-86{ }^{\circ} \mathrm{C} ; R_{\mathrm{f}}=0.5$; ESI-MS $(m / z)=226(\mathrm{M}+1) ;{ }^{1} \mathrm{H}$ NMR $(400 \mathrm{MHz}$, DMSO-d 6$): 8.21-$ 8.37 (m, 2H, ArH-8, 9), 7.42-7.92 (m, 1H, ArH-6), 7.54 (d, 2H, ArH-2, 3, $J=7.8 \mathrm{~Hz}$ ), 7.40-7.48 (m, 1H, ArH-7), 7.18 (d, 2H, ArH$1,2, J=8.0 \mathrm{~Hz}$ ), 2.31 (s, 3H, $\left.\mathrm{CH}_{3}\right) ;{ }^{13} \mathrm{C}$ NMR (75.45 MHz, DMSO$\left.\mathrm{d}_{6}\right)$ : 21.3, 121.7, 123.2, 125.2, 125.5, 126.4, 132.9, 133.5, 135.1, $138.9,154.1,168.7$.
2-(4-Methoxylphenyl)-benzothiazole 5g. $\mathrm{Mp} 120-122{ }^{\circ} \mathrm{C} ; R_{\mathrm{f}}=$ 0.65; ESI-MS $(m / z)=242(\mathrm{M}+1) ;{ }^{1} \mathrm{H}$ NMR (400 MHz, DMSO-d 6 ): 8.16-8.32 (m, 2H, ArH-8, 9), 7.48-7.98 (m, 1H, ArH-6), 7.56 (d, $2 \mathrm{H}, \operatorname{ArH}-1,2, J=7.8 \mathrm{~Hz}), 7.42-7.50(\mathrm{~m}, 1 \mathrm{H}, \operatorname{ArH}-7), 7.15(\mathrm{~d}, 2 \mathrm{H}$, ArH-1, 2, $J=8.0 \mathrm{~Hz}$ ), $3.85\left(\mathrm{~s}, 3 \mathrm{H}, \mathrm{CH}_{3}\right) ;{ }^{13} \mathrm{C} \mathrm{NMR}(75.45 \mathrm{MHz}$, DMSO-d ${ }_{6}$ ): 54.3, 121.8, 123.7, 125.8, 126.7, 127.4, 130.3, 135.4, 137.4, 144.4, 154.2, 166.4.

2-Phenyl-benzoxazole 7a. Mp 98-100 ${ }^{\circ} \mathrm{C} ; R_{\mathrm{f}}=0.5$; ESI-MS $(\mathrm{m} /$ $z)=196(\mathrm{M}+1) ;{ }^{1} \mathrm{H}-\mathrm{NMR}\left(400 \mathrm{MHz}, \mathrm{CDCl}_{3}\right), 8.24(\mathrm{~d}, 2 \mathrm{H}, \mathrm{ArH}-8$, $9, J=7.5 \mathrm{~Hz}$ ), $7.76(\mathrm{dd}, 1 \mathrm{H}, \mathrm{ArH}-5, J=3.3 \mathrm{~Hz}, J=3.0 \mathrm{~Hz}), 7.52-$ 7.60 (m, 4H, ArH-6, 7, 3, 4), 7.34-7.37 (m, 2H, ArH-1, 2); ${ }^{13} \mathrm{C}-$ NMR (75.45 MHz, DMSO) 121.6, 122.3, 123.5, 124.6, 125.4, 129.4, 132.3 138.5, 150.6, 154.2, 162.2. Anal. calcd for $\mathrm{C}_{13} \mathrm{H}_{9} \mathrm{NO}$ : C 79.98, H 4.65, N 7.17; found: C 79.87, H 4.51, N 7.06.

2-(4-Chlorophenyl)-benzoxazole $7 \mathrm{~b}$. Mp $142-146{ }^{\circ} \mathrm{C} ; R_{\mathrm{f}}=$ 0.45; ESI-MS $(\mathrm{m} / \mathrm{z})=229\left(\mathrm{M}^{+}\right) ;{ }^{1} \mathrm{H}$ NMR (400 MHz, DMSO-d $\left.{ }_{6}\right)$ : 8.11-8.19 (m, 2H, ArH-8, 9), 7.65 (d, 2H, ArH-6, 7, $J=7.6 \mathrm{~Hz}$ ), 7.52-7.60 (m, 1H, ArH-3), 7.35-7.86 (m, 1H, ArH-4), 7.28 (d, 2H, ArH-1, 2, $J=8.6 \mathrm{~Hz}) ;{ }^{13} \mathrm{C}-\mathrm{NMR}$ (75.45 MHz, DMSO) 121.6, 122.3, 123.5, 124.6, 125.4, 129.4, 132.3, 138.5, 150.6, 154.2, 162.2.

2-(3,4-Dimethoxy phenyl)-benzoxazole 7c. Mp 109-112 ${ }^{\circ} \mathrm{C} ; R_{\mathrm{f}}$ $=0.55$; ESI-MS $(\mathrm{m} / \mathrm{z})=255\left(\mathrm{M}^{+}\right) ;{ }^{1} \mathrm{H}-\mathrm{NMR}\left(400 \mathrm{MHz}, \mathrm{CDCl}_{3}\right)$, 7.77 (d, $1 \mathrm{H}, J=1.96 \mathrm{~Hz}, \mathrm{ArH}-8), 7.66-7.69$ (m, 2H, ArH-6, 7), 7.47-7.50 (m, 1H, ArH, 9), 7.23-7.28 (m, 2H, ArH-3, 4), 6.90 (d, $1 \mathrm{H}, \mathrm{ArH}-4, J=8.08 \mathrm{~Hz}), 3.94\left(\mathrm{~s}, 3 \mathrm{H}, \mathrm{OCH}_{3}\right), 3.89$ (s, 3H, $\left.\mathrm{OCH}_{3}\right)$; ${ }^{13} \mathrm{C}-\mathrm{NMR}$ (75.45 MHz, DMSO) 54.8, 55.1, 121.6, 122.4, 123.0, 124.5, 126.7, 128.9, 131.8, 137.4, 150.6, 152.6, 165.0. Anal. calcd for $\mathrm{C}_{15} \mathrm{H}_{13} \mathrm{NO}_{3}$ : C 70.59, $\mathrm{H} 5.13, \mathrm{~N} 5.49$; found: $\mathrm{C} 70.57, \mathrm{H} 4.98, \mathrm{~N}$ 5.46 .

2-(4-Nitro phenyl)-benzoxazole 7d. Mp 262-264 ${ }^{\circ} \mathrm{C} ; R_{\mathrm{f}}=0.5$; ESI-MS $(m / z)=240\left(\mathrm{M}^{+}\right) ;{ }^{1} \mathrm{H}-\mathrm{NMR}\left(400 \mathrm{MHz}, \mathrm{CDCl}_{3}\right), 8.43-8.46$ (m, 2H, ArH-8, 9), 8.38-8.41 (m, 2H, ArH-6, 7), 7.82-7.84 (m, 1H, ArH-3), 7.63-7.65 (m, 1H, ArH-4), 7.40-7.47 (m, 2H, ArH-1, 2); ${ }^{13}$ C-NMR (75.45 MHz, DMSO) 120.9, 121.8, 122.8, 124.9, 126.8, $130.0,131.7,137.5,151.6,153.2,163.2$. Anal. calcd for $\mathrm{C}_{13} \mathrm{H}_{8} \mathrm{~N}_{2} \mathrm{O}_{3}$ : C 65, H 3.33, N 11.66; found: C 64.78, H 3.40, N 11.58 .

2-(4-Hydroxyphenyl)-benzoxazole 7e. $\mathrm{Mp} 284-286{ }^{\circ} \mathrm{C} ; R_{\mathrm{f}}=$

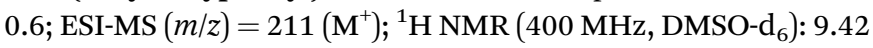
(s, 1H, OH), 8.16-8.32 (m, 2H, ArH-8, 9), 7.41-7. 57 (m, 1H, ArH6), 7.56 (d, 2H, ArH-3, 4, $J=7.6 \mathrm{~Hz}), 7.42-7.50$ (m, 1H, ArH-7), 7.27 (d, 2H, ArH-1, 2, $J=8.4 \mathrm{~Hz}$ ); ${ }^{13} \mathrm{C}-\mathrm{NMR}(75.45 \mathrm{MHz}$, DMSO) 121.0, 121.8, 122.0, 123.9, 125.8, 130.9, 131.7, 137.2, 152.6, 153.2, 163.8 .

2-(4-Methylphenyl)-benzoxazole 7f. Mp $122-124{ }^{\circ} \mathrm{C}$; ESI-MS $(\mathrm{m} / \mathrm{z})=209\left(\mathrm{M}^{+}\right) ;{ }^{1} \mathrm{H}$ NMR $\left(400 \mathrm{MHz}, \mathrm{DMSO}-\mathrm{d}_{6}\right): 8.06-8.22(\mathrm{~m}$, 2H, ArH-8, 9), 7.24-7.74 (m, 1H, ArH-6), 7.56 (d, 2H, ArH-3, 4, J= $7.6 \mathrm{~Hz}$ ), 7.41-7.49 (m, 1H, ArH-7), 7.26 (d, 2H, ArH-1, 2, J=8.0 $\mathrm{Hz}$ ), 2.31 (s, 3H, $\mathrm{CH}_{3}$ ); ${ }^{13} \mathrm{C}$ NMR (75.45 MHz, DMSO-d 6 ): 21.3, $110.7,119.6,123.4,124.8,126.4$, 127.4, 129.6, 138.4, 141.5, $150.4,162.2$.

2-(4-Methoxy phenyl)-benzoxazole $7 \mathrm{~g} . \mathrm{Mp} 98-100{ }^{\circ} \mathrm{C} ; R_{\mathrm{f}}=$ 0.6; ESI-MS $(\mathrm{m} / \mathrm{z})=226(\mathrm{M}+1) ;{ }^{1} \mathrm{H}-\mathrm{NMR}\left(400 \mathrm{MHz}, \mathrm{CDCl}_{3}\right)$; 8.11-8.13 (m, 2H, ArH-8, 9), 7.65-7.67 (m, 1H, ArH-6), 7.46-7.49 (m, 1H, ArH-7), 7.23-7.26 (m, 2H, ArH-3, 4), 6.94-6.96 (m, 2H, $\mathrm{ArH}-1,2), 3.81$ (s, 3H, $\left.\mathrm{OCH}_{3}\right) ;{ }^{13} \mathrm{C}-\mathrm{NMR}\left(\mathrm{CDCl}_{3}, 75.45 \mathrm{MHz}\right)$ : 
54.2, 109.3, 113.3, 118.5, 120.5, 124.7, 125.6, 128.3, 141.0, 149.5, 162.1, 163.7. Anal. calcd for $\mathrm{C}_{14} \mathrm{H}_{11} \mathrm{NO}_{2}$ : C 74.65, $\mathrm{H}$ 4.92, N 6.22; found: C 74.42, H 4.79, N 6.11.

\section{Conflicts of interest}

Author has no conflict of interest.

\section{Acknowledgements}

We are grateful thanks to Chandigarh and Punjab University, Chandigarh for spectral analytical data.

\section{References}

1 (a) C. Chen and Y. J. Chen, Tetrahedron Lett., 2004, 45, 113; (b) N. Siddiqui, A. Rana, S. A. Khan, M. A. Bhat and S. E. Haque, Bioorg. Med. Chem. Lett., 2007, 17, 4178; (c) C. J. Lion, C. S. Matthews, G. Wells, T. D. Bradshaw, M. F. G. Stevens and A. D. Westwell, Bioorg. Med. Chem. Lett., 2006, 16, 5005; (d) S. T. Huang, I. J. Hsei and C. Chen, Bioorg. Med. Chem., 2006, 14, 6106.

2 (a) J. L. Girardet and L. B. J. Townsend, J. Org. Chem., 1999, 64, 4169; (b) C.-M. Yeh, C.-L. Tung and C.-M. Sun, J. Comb. Chem., 2000, 2, 341; (c) J. J. Chen, Y. Wei, J. C. Drach and L. B. Townsend, J. Med. Chem., 2000, 43, 2449; (d) D. Tumelty, K. Cao and C. P. Holmes, Org. Lett., 2001, 3, 83; (e) J. Mann, A. Baron, Y. Opoku-Boahen, E. Johansson, G. Parkinson, L. R. Kelland and S. Neidle, J. Med. Chem., 2001, 44, 138; (f) B. Raju, N. Nguyen and G. W. Holland, J. Comb. Chem., 2002, 4, 320; (g) H. Akamatsu, K. Fukase and S. Kusumoto, J. Comb. Chem., 2002, 4, 475; (h) C. E. Hoesl, A. Nefzi and R. A. Houghten, J. Comb. Chem., 2003, 5, 155; (i) D. Vourloumis, M. Takahashi, K. B. Simonsen, B. K. Ayida, S. Barluenga, G. C. Winters and T. Hermann, Tetrahedron Lett., 2003, 44, 2807.

3 (a) D.-F. Shi, T. D. Bradshaw, S. Wrigley, C. J. McCall, P. Lelieveld, I. Fichtner and M. F. G. Stevens, J. Med. Chem., 1996, 39, 3375; (b) X. Beebe, D. Wodka and T. J. Sowin, J. Comb. Chem., 2001, 3, 360; (c) A. Hari, C. Karan, W. C. Rodrigues and B. L. Miller, J. Org. Chem., 2001, 66, 991; (d) R. S. Pottorf, N. K. Chadha, M. Katkevics, V. Ozola, E. Suna, H. Ghane, T. Regberg and M. R. Player, Tetrahedron Lett., 2003, 44, 175; (e) F. Chen, C. Shen and D. Yang, Tetrahedron Lett., 2011, 52, 2128.

4 (a) M.-S. Chua, D.-F. Shi, S. Wrigley, T. D. Bradshaw, I. Hutchinson, P. N. Shaw, D. A. Barrett, L. A. Stanley and M. F. G. Stevens, J. Med. Chem., 1999, 42, 381; (b) E. Kashiyama, I. Hutchinson, M.-S. Chua, S. F. Stinson, L. R. Phillips, G. Kaur, E. A. Sausville, T. D. Bradshaw, A. D. Westwell and M. F. G. Stevens, J. Med. Chem., 1999, 42, 4172; (c) I. Hutchinson, M.-S. Chua, H. L. Browne, V. Trapani, T. D. Bradshaw, A. D. Westwell and M. F. G. Stevens, J. Med. Chem., 2001, 44, 1446; (d) W. Leng, Y. Zhou, Q. Xu and J. Liu, Macromolecules, 2001, 34, 4774; (e) I. Hutchinson, S. A. Jennings,
B. R. Vishnuvajjala, A. D. Westwell and M. F. G. Stevens, J. Med. Chem., 2002, 45, 744.

5 (a) V. Kannan and K. Sreekumar, J. Mol. Catal. A: Chem., 2013, 376, 34; (b) J. Yuan, Z. Zhao, W. Zhu, H. Li, X. Qian and Y. Xu, Tetrahedron, 2013, 69, 7026; (c) Y. H. Cho, C. Y. Lee and C. H. Cheon, Tetrahedron, 2013, 69, 6565; (d) G. Bramhachari, S. Laskar and P. Barik, RSC Adv., 2013, 3, 14245; (e) A. Teimouri, A. N. Chermahini, H. Salavati and L. Ghorbanian, J. Mol. Catal. A: Chem., 2013, 373, 38; (f) S. Santra, A. Majee and A. Hajra, Tetrahedron Lett., 2012, 53, 1974; $(g)$ M. M. Guru, M. A. Ali and T. Punniyamurthy, J. Org. Chem., 2011, 76, 5295; (h) J. P. Wan, S. F. Gan, J. M. Wu and Y. Pan, Green Chem., 2009, 11, 1633.

6 (a) N. B. Valentin, J. B. Patrick, A. M. John, J. S. Colin and L. Stuart, J. Org. Chem., 2013, 78, 1471; (b) H. C. Yeon, Y. L. Chun, C. H. Deok and H. C. Cheol, Adv. Synth. Catal., 2012, 354, 29926; (c) S. Hashem, A. Mahdi and M. D. Mohammad, J. Iran. Chem. Soc., 2012, 9, 189; (d) R. Yassin, M. Rachid, A. Rachid, E. H. Mohammadine, R. Sylvain, G. Geraid and L. Said, Tetrahedron Lett., 2011, 52, 3492; (e) W. Ying, S. Kathy, R. S. Daryl and W. D. Stevan, Tetrahedron Lett., 2006, 47, 4823.

7 (a) R. J. Perry, B. D. Wilson and R. J. Miller, J. Org. Chem., 1992, 57, 2883; (b) D. Alagille, R. M. Baldwin and G. D. Tamagnan, Tetrahedron Lett., 2005, 46, 1349; (c) C. Benedi, F. Bravo, P. Uriz, E. Fernandez, C. Claver and S. Castillon, Tetrahedron Lett., 2003, 44, 6073; (d) R. S. Varma, R. K. Saini and O. Prakash, Tetrahedron Lett., 1997, 38, 2621; (e) R. S. Varma and D. Kumar, J. Heterocycl. Chem., 1998, 35, 1533; (f) K. Bougrin, A. Loupy and M. Souuflaoui, Tetrahedron, 1998, 54, 8055; $(g)$ T. Yoshiyuki, Y. Kazuaki and K. H. Hokkaido Daigaku Koagakubu, Chem. Abstr., 1980, 93, 45-49204537k; (h) L. S. Gadekar, B. R. Arbad and M. K. Lande, Chin. Chem. Lett., 2010, 21, 1053; (i) M. Lei, L. Ma and L. Hu, Synth. Commun., 2012, 42, 2981; (j) R. Fazaeli and H. Aliyan, Appl. Catal., A, 2009, 353, 74; (k) C. Mukhopadhyay and A. Datta, Heterocycles, 2007, 71, 1837; (l) D. L. Boger, J. Org. Chem., 1978, 43, 2296; $(m)$ M. Kodomari, Y. Tamaru and T. Aoyama, Synth. Commun., 2004, 34, 3029; (n) S. E. López, J. Restrepo, B. Pérez, S. Ortiz and J. Salazar, Bull. Korean Chem. Soc., 2009, 30, 1628; (o) V. R. Devalla and K. Ethirajulu, J. Chem. Soc., 1995, 1497; (p) A. Teimouri, A. N. Chermahini, H. Salavati and L. Ghorbanian, J. Mol. Catal. A: Chem., 2013, 373, 38; (q) D. Yang, X. Zhu, W. Wei, N. Sun, L. Yuan, M. Jiang, J. You and H. Wang, RSC Adv., 2014, 4, 17832; (r) D. Yang, X. Zhu, W. Wei, M. Jiang, N. Zhang, D. Ren, J. You and H. Wang, Synlett, 2014, 25, 0729; (s) D. Yang, K. Yan, W. Wei, L. Tian, Y. Shuai, R. Li, J. You and H. Wang, Asian J. Org. Chem., 2014, 3, 969; $(t)$ D. Yang, P. Liu, N. Zhang, W. Wei, M. Yue, J. You and H. Wang, ChemCatChem, 2014, 6, 3434.

8 N. Ahmet, Z. K. Birgul and M. Z. Luis, Z. Anorg. Allg. Chem., 2009, 635, 1470.

9 (a) M. S. Newton, J. D. Morrison, R. D. Pennell, N. P. Phodes and A. J. Toft, US Pat., Appl., 203152, 2010; (b) V. Rives, Layered double hydroxides: present and future, Nova Science 
Publishers, New York, 2001; (c) S. K. Sharma, P. A. Parikh and R. V. Jarra, J. Mol. Catal. A: Chem., 2007, 278, 135; (d) C. O. Veloso, C. N. Perez, B. M. de Souza, E. C. Lima, A. G. Dias, J. L. F. Monteiro and C. A. Henriques, Microporous Mesoporous Mater., 2008, 107, 23.

10 (a) W. Kagunya, Z. Hassan and W. Janes, Inorg. Chem., 1994, 35, 5970; (b) M. Ulibarri, F. M. Labajos, V. Rives, R. Trujillano, W. Kagunya and W. Janes, Inorg. Chem., 1994, 33, 2592.

11 C. M. Jinesh, C. A. Antonyraj and S. Kannan, Catal. Today, 2009, 141, 176.

12 (a) M. A. Ulibarri, I. Pavlovic, C. Barriga, M. C. Hermosin and J. Cornejo, Appl. Clay Sci., 2001, 18, 17; (b) G. Centi and S. Perathoner, Microporous Mesoporous Mater., 2008, 107, 3.

13 K. Motocura, N. Fujita, K. Mori, T. Mizugaki, K. Ebitani, K. Htsukawa and K. Kanedar, Chem.-Eur. J., 2006, 12, 8228.

14 M. Turco, G. Bagnasco, U. Costantino, F. Marmottini, T. Montanari, G. Ramis and G. Busca, J. Catal., 2004, 228, 56.

15 B. F. Sels, D. E. De Vos and P. A. Jacobs, Catal. Rev.: Sci. Eng., 2001, 43, 443.

16 Y. Xi and R. J. Davis, J. Catal., 2008, 254, 190.

17 S. K. Yun and T. Pinnavaia, J. Mater. Chem., 1995, 7, 348.

18 (a) P. K. Sahu, P. K. Sahu, S. K. Gupta, D. Thavaselvam and D. D. Agarwal, Eur. J. Med. Chem., 2012, 54, 366; (b) P. K. Sahu, P. K. Sahu, D. Thavaselvam, A. M. Alafeefy and D. D. Agarwal, Med. Chem. Res., 2015, 24, 725; (c) P. K. Sahu, P. K. Sahu and D. D. Agarwal, RSC Adv., 2013, 3, 9854; (d) P. K. Sahu, P. K. Sahu, S. K. Gupta and D. D. Agarwal, Ind. Eng. Chem. Res., 2014, 53, 2085; (e) P. K. Sahu, P. K. Sahu, S. K. Gupta and D. D. Agarwal, Catal. Sci. Technol., 2013, 3, 1520; (f) P. K. Sahu, P. K. Sahu and D. D. Agarwal, $R S C A d v ., 2014,4$, 40414; $(g)$ P. K. Sahu, P. K. Sahu, Y. Sharma and D. D. Agarwal, J. Heterocycl. Chem., 2014, 51, 1193; (h) P. K. Sahu, P. K. Sahu and D. D. Agarwal, J. Indian Chem. Soc., 2015, 92, 169.

19 S. J. Palmer, T. Nauyen and R. L. Frost, Coord. Chem. Rev., 2009, 253, 250.

20 S. J. Palmer and R. L. Frost, Ind. Eng. Chem. Res., 2011, 50, 5346.

21 M. Valcheva-Traykova, N. Davidova and A. Weiss, J. Mater. Sci., 1993, 28, 2157.

22 F. Cavani, F. Trifiro and A. Vaccari, Catal. Today, 1991, 11, 173.

23 F. M. Labojos, V. Rives and M. A. Ulibarri,J. Mater. Sci., 1992, 27, 1546.

24 A. S. Bookin and A. Dritis, Clays Clay Miner., 1993, 41, 551. 25 W. T. Reichle, CHEMTECH, 1986, 16, 58.

26 K. R. Kottapalli, G. Monique, S. V. Jaime and F. Francois, J. Catal., 1998, 173, 115.

27 (a) Y. Liu, E. Lotero, J. J. Goodwin and X. Mo, Appl. Catal., A, 2007, 331, 138; (b) P. Chauyplod and W. Trakarnpruk, Ind. Eng. Chem. Res., 2009, 48, 4177.

28 (a) D. G. Cantrell, L. J. Gillie, A. F. Lee and K. Wilson, Appl. Catal., A, 2005, 287, 183; (b) J. M. Fraile, N. Garcia, J. A. Mayoral, E. Pires and L. Rodan, Appl. Catal., A, 2009, 364, 87; (c) H. J. Hattori, J. Jpn. Pet. Inst., 2004, 47, 67.

29 J. J. Di Cosimo, V. K. Di'ez, M. Xu, E. Iglesia and C. R. Apesteguia, J. Catal., 1998, 178, 499.

30 (a) T. Nakatsuka, H. Kawasaki, S. Yamashita and S. Kohjiya, Bull. Chem. Soc. Jpn., 1979, 52, 2449; (b) C. T. Fishel and R. Davis, Langmuir, 1994, 10, 159. 